\title{
The Relationship between Islamic Piety (Taqwa) and Workplace Deviance with Organizational Justice as a Moderator
}

\author{
Omar Khalid Bhatti ${ }^{1}$, Ali Alkahtani ${ }^{2}$, Arif Hassan ${ }^{1,3} \&$ Mohamed Sulaiman ${ }^{1,3}$ \\ ${ }^{1}$ Department of Economics and Management Sciences, International Islamic University Malaysia, Malaysia \\ ${ }^{2}$ King Abdul Aziz University Jeddah, Saudi Arabia \\ ${ }^{3}$ Faculty of Graduate School of Management, International Islamic University Malaysia, Malaysia \\ Correspondence: Omar Khalid Bhatti, Department of Economics and Management, International Islamic \\ University Malaysia, Kuala Lumpur, Malaysia. Tel: 60-1-4931-0241. E-mail: omar.k.bhatti@gmail.com
}

Received: January 4, 2015

Accepted: February 9, $2015 \quad$ Online Published: March 27, 2015

doi:10.5539/ijbm.v10n4p136

URL: http://dx.doi.org/10.5539/ijbm.v10n4p136

\begin{abstract}
Workplace deviance among employees is one of the most prevalent issues faced by today's organizations globally. Many scholars are keen in studying this phenomenon of workplace deviance because of its high rate of occurrence and severe negative impact on organizations. Research supports the belief that workplace spirituality programs may result in encouraging positive outcomes and can benefit organizations with employees who are more principled, committed, productive, adaptive and innovative. Although, past studies on workplace deviance are well documented, providing an understanding as how situational or individual antecedents may lead to workplace deviance, the problem of workplace deviance remains. Particularly has not been studied from an Islamic perspective. Islam being a comprehensive religion and a complete code of life can provide a suitable solution to manage such an issue. Islamic Piety (Taqwa) is one the most important characteristic of a Muslim. Significantly Islamic spiritual and social responsibility both fall under the purview of Taqwa. An individual holding on to Islamic Piety (Taqwa) can showcase the best of his/her behavior. Therefore the current conceptual study intends to investigate the direct relationships between Taqwa and workplace deviance. In addition this study also proposes to investigate the moderating role of perceived organizational justice (a situational antecedent) between Taqwa and workplace deviance.
\end{abstract}

Keywords: workplace deviance, spirituality, responsibility, organizational justice, Taqwa (Islamic Piety)

\section{Introduction}

In today's speedy and competitive business world organizations encourage directors, senior executives and managers to improve organizational effectiveness. Organizational effectiveness can be attained through establishing positive behavior among employees and ensuring that they do not engage in negative behavior (Nurmaya, 2012). Having too many employees with negative behavior will dampen the organization's objective for achieving effectiveness as well as put at risk the wellbeing of the stakeholders (Pulich \& Tourigny, 2004; McCardle, 2007; Nurmaya, 2012). There are several forms of negative behavior, out of which workplace deviance is one of the most frequently studied. Workplace deviance is a behavior that defies and violates the norms of the organization (Griffin \& Lopez, 2005). In particular, deviant behavior is a voluntary behavior that breaks important organizational norms and threatens to damage the organization, its members or both (Robinson \& Bennett, 1995).

Many researchers are interested in studying workplace deviance because of its high rate of occurrence and serious negative impact on organizations. Workplace deviance appears in the form of a number of employee behaviors. Earlier studies report that nearly $75 \%$ of employees involve in workplace deviance like theft, fraud, vandalism, sabotage and voluntary absenteeism (Harper, 1990; Gross-Schaefer et al., 2000; Lawrence \& Robinson, 2007; Chirasha \& Mahapa, 2012). It is affirmed that majority of organizations have experienced theft by their own employees (Case, 2000), causing financial losses of between $\$ 50$ and $\$ 200$ billion annually on the US economy (Chirasha \& Mahapa, 2012). KPMG-UK fraud barometer for 2013 confirms that identity fraud in 2012 reached to a level high of $£ 26.3$ million from $£ 12.3$ million the year before. Forged goods scam rose to $£ 22.9$ million with ponzi schemes worth $£ 72$ million came to courts. The report also presents a similar rising 
trend for procurement fraud, which grew to $£ 21.4$ million in 2012. What's more, the number of cases involving employee fraud increased to 35 in 2012 from 22 as compared to 2011, with values climbing from £12.0 million (2011) to £ 25.1 million in 2012.

In answering questions as to why employees engage in deviant behavior, researchers (Aquino, Lewis, \& Bradfield, 1999; Vardi, 2001; Colbert, Mount, Harter, Witt, \& Barrick, 2004) have classified antecedents of workplace deviance into two categories: situational and individual. Situational antecedents include justice (Aquino et al., 1999; Aquino, Galperin, \& Bennett, 2004; Berry, Ones, \& Sackett, 2007), perceived work situation and perceived organizational support (Colbert et al., 2004), socialized charismatic leadership (Brown \& Trevino, 2006) and abusive supervisor (Mitchell \& Ambrose, 2007). Individual antecedents include trait anger (Douglas \& Martinko, 2001), motivational trait (Diefendorff \& Mehta, 2007), negative affectivity (Aquino et al., 1999; Douglas \& Martinko, 2001) the Big Five traits (Colbert et al., 2004).Therefore, situational and individual deviance helps to answer as to why employees engage in workplace deviance. Notably in the last few years the most readily investigated situational antecedent of workplace deviance is perceived organizational justice (Colquitt, 2001; McCardle, 2007; Nurmaya, 2012).

Perceived organizational justice refers to the individuals and the group's perception of the fairness of treatment received from an organization and their behavioral reaction to such perceptions (Aryee, Budhwar, \& Chen, 2002).The justice construct has developed and evolved over time, moreover, has been studied on four dimensions, those of Distributive justice, Procedural justice, Interpersonal justice and Informational justice (Colquitt, 2001; Colquitt \& Rodell, 2011). The negative relationship between perceived organizational justice and workplace deviance has been well documented. The past studies certainly help in providing an understanding on how perceived organizational justice may lead to workplace deviance. However, the problem of workplace deviance is prevailing and is a key area of interest for academicians and practitioners (McCardle, 2007; Nurmaya, 2012).

Spirituality is expected to stimulate employee's honesty, creativity, commitment and personal fulfillment (Krishnakumar \& Neck, 2002). Research supports the belief that workplace spirituality programs in an organization do certainly result in encouraging positive outcomes, like increased joy, serenity, job satisfaction, and commitment (Krishnakumar \& Neck, 2002; Fry, 2003; Giacalone \& Jurkiewicz, 2003; Reave, 2005). Organizations that support and encourage spiritual and caring work environments not only benefit from employees who are less apprehensive and more principled but also see an increase in the commitment, productivity, adaptability and innovation in their employees (Eisler \& Montouori, 2003; Mat \& Naser, 2012).

Islam is a complete way of life and the main and the most recurrent characteristic, which Allah (SWT) directed the Messengers and all believers to hold onto in Quran, is Taqwa (Islamic piety). Taqwa and its derivatives are mentioned 258 times in Quran. Quran is full of its many traits and characteristics that have been related with Prophets (may peace be upon all of them) such as honesty, tolerance, Iman (belief), forgiveness and kindness (Sulaiman, Mohsen, \& Kamil, 2013). Magnificence of Taqwa is that it encompasses most of these characteristics, with major emphasis on Iman (belief) as it is the most common among Prophets (Sulaiman et al., 2013). More importantly, in Islam spirituality and social responsibility both fall under the purview of Taqwa (Islamic Piety). Taqwa is to obey Allah's orders and to stay away for all that has been forbidden by Him, in such a way that we strive towards the light of His guidance, acceptance and rewards and fear His torment and severe punishment in the hereafter (Kamil, Sulaiman, Osman-Gani, \& Ahmad, 2011). The theoretical definition of Islamic spirituality is the responsibility between one's self and Allah (Kamil, Al-Kahtani \& Sulaiman, 2011b; Kamil et al., 2011; Mohsen, 2007) and theoretically Islamic Social responsibility is the responsibility to one's self and other human beings and nature at large (Kamil et al., 2011; Mohsen, 2007).

The current study attempts to establish the negative relationship between Taqaw (Islamic Piety) and workplace deviance which has not been studied before. In addition, this study also intends to investigate the moderating role of perceived organizational justice between Taqwa and workplace deviance.

Likewise, this study aims at adding another dimension to the antecedents of workplace deviance in the form of social responsible behavior of employees (social responsibility at individual level). The social responsibility has been mostly studied at the corporate level, wherein a corporation is treated as a social citizen (Appelbaum, Iaconi, \& Matousek, 2007; Kolodinsky, Madden, Zisk, \& Henkel, 2010). However, an organization being a microcosm of a society, the socially responsible behavior of its members is expected to affect the overall behavior of the organization.

The present study is guided by the following research questions; (1) Does Taqwa (consisting of Islamic spirituality and Islamic social responsibility) affect workplace deviance? (2) Does perceived organizational 
justice act as moderator in the relationship between Taqwa and workplace deviance?

\section{Literature Review}

"Decades of research show that fairness perceptions can substantially contribute to various attitudinal, cognitive, emotional, and behavioral outcomes among organizational members" (McCardle, 2007, p. 2). When employees in an organization believe that they are treated unduly, they are likely to experience feelings of anger, outrage, frustration, and a desire for revenge (Greenberg, 1990a; Bies \& Tripp, 1996). Under certain situations and conditions, these negative feelings can manifest into workplace deviance (Robinson \& Bennett, 1995). Where, workplace deviance refers to counterproductive behavior in organizations (Griffin \& Lopez, 2005). However, academic researchers over the time have defined workplace deviance differently. Table 1 highlights some of the major definitions used for workplace deviance.

Table 1. Definition's for workplace deviance

\begin{tabular}{|c|c|}
\hline Author and Year & Definition \\
\hline $\begin{array}{l}\text { Hollinger and Clark (1982) } \\
\text { Mangione and Quinn (1974) }\end{array}$ & $\begin{array}{l}\text { Voluntary behavior where an employee either lacks motivation to accomplish the expectation of } \\
\text { normative social context or becomes motivated to violate those expectations. }\end{array}$ \\
\hline Robinson and Bennett (1995) & $\begin{array}{l}\text { Voluntary behavior that violates significant organizational norms and in so doing threatens the } \\
\text { wellbeing of an organization, its members, or both. }\end{array}$ \\
\hline Giacalone and Greenberg (1997) & $\begin{array}{l}\text { Actions that bring harm or would intended to bring harm, to an organization, its employees, and/or the } \\
\text { organization's stakeholders. }\end{array}$ \\
\hline Sackett and DeVore (2001) & $\begin{array}{l}\text { Any intentional behavior on the part of an organization member that is viewed by the organization as } \\
\text { divergent and contrary to its valid or legitimate interests. }\end{array}$ \\
\hline Warren $(2003)$ & Behavioral departures from the norms of a reference group. \\
\hline McCardle (2007) & $\begin{array}{l}\text { Workplace deviant behavior entails a constellation of employee behaviors that deviate from } \\
\text { organizational norms espoused by the dominant administrative coalition }\end{array}$ \\
\hline $\begin{array}{l}\text { Omar, Halim, Zainah, Farhadi, } \\
\text { Nasir and Kairudin (2011) }\end{array}$ & $\begin{array}{l}\text { Workplace deviance is described as the deliberate or intentional desire to cause harm to an } \\
\text { organization }\end{array}$ \\
\hline Sulaiman and Omar (2013b) & $\begin{array}{l}\text { Workplace deviance is an act of violating the set standards of performance as set by an organization, } \\
\text { causing harm to the organization and its members }\end{array}$ \\
\hline
\end{tabular}

Source: (Bennett \& Robinson, 2003; Fagbohungbe et al., 2012; McCardle, 2007; Nurmaya, 2012; Sulaiman \& Bhatti, 2013b).

The most commonly cited definition of workplace deviance by researchers is one presented by Robinson and Bennett (1995). They define workplace deviance as "voluntary behavior that violates important organizational rules and in doing so threatens the wellbeing and interests of an organization, its members, or both" (Robinson \& Bennett, 1995, p. 556). In the definition, the term "voluntary behavior" refers to deviant behavior where an employee lacks motivation to fulfill the expectations of normative social context or becomes motivated to defy and violate those expectations (Kaplan, 1975). Griffin and Lopez (2005) affirm that voluntary behavior is more of an intentional behavior rather than an accidental behavior.

A number of the researchers (Mangione \& Quinn, 1974; Hollinger \& Clark, 1982; Robinson \& Bennett, 1995; Kidwell \& Martin, 2004; Spector \& Fox, 2005; McCardle, 2007; Bordia, Restubog, \& Tang, 2008; Nurmaya, 2012) envisage workplace deviance as negative and destructive in nature. Whereas, Warren (2003) affirms that the nature of workplace deviance can be constructive as well as destructive. It is not necessary that it would always harm or damage an organization, but can also bring benefits to the organization (Warren, 2003). For instance, "A researcher who develops a revolutionary vaccine for a deadly disease may exhibit behavior that departs from the creative norms of a workgroup, but does so in the benefit of the organization and a larger society. This clarifies that deviances can be seen as a constructive behavior to the organization" (Warren, 2003, p. 629). However, the justification presented by Warren (2003) has a narrow acceptability, given that most of the researchers and scholars (for instance, Mangione, \& Quinn, 1974; Hollinger \& Clark, 1982; Robinson \& Bennett, 1995; Kidwell \& Martin, 2004; Spector \& Fox, 2005; McCardle, 2007; Bordia, Restubog, \& Tang, 2008; Nurmaya, 2012) perceive workplace deviance as negative rather than positive for an organization. Therefore, this study accounts workplace deviance as negative and adopts the definition presented by Robinson and Bennett (1995), as it covers organizational as well as interpersonal deviance. 


\subsection{Workplace Deviance and Similar Concepts}

Workplace deviance covers a wide array of behaviors that may possibly damage or deliberately harm the stakeholders of the organization (Spector \& Fox, 2005). Notably, workplace deviance has been reviewed and studied under the terms such as aggression, violence, workplace incivility, retaliation, counter productivity, revenge, dysfunctional behavior, organizational misbehavior, unconventional practices at work, noncompliance behavior and general antisocial behavior (Anderson \& Pearson, 1999; Griffin \& Lopez, 2005; Spector \& Fox, 2005; McCardle, 2007; Fagbohungbe et al., 2012). The stated behaviors are deemed as damaging and counterproductive, conceptually and in theory they are different from one another (McCardle, 2007; Nurmaya, 2012). The difference between the concepts exists on basis of intensity, target and intension as shown in the table 2.

Table 2. Workplace deviance and similar concepts

\begin{tabular}{llll}
\hline Concept & Target & Intention & Intensity \\
\hline Antisocial Behavior & Organizational/Personal & $\begin{array}{l}\text { Unclear, could be norms violation and /or } \\
\text { others }\end{array}$ & From very low to very high \\
\hline Workplace Deviance & Organizational/Personal & To violate organizational norms & Low until high \\
\hline Violence & Personal & To harm physically & Very high \\
\hline Aggression & Organizational/Personal & To harm and injure & Medium and high \\
\hline Incivility & Personal & $\begin{array}{l}\text { Ambiguous, could be with or without } \\
\text { intension to harm }\end{array}$ & Very low \\
\hline
\end{tabular}

Source: (Anderson \& Pearson, 1999; Bennett \& Robinson, 2003; Fagbohungbe et al., 2012; Nurmaya, 2012).

\subsection{Workplace Deviance and Its Classification}

Robinson and Bennett (1995) classified workplace deviance based on two dimensions namely: target and the severity. Derived from these two dimensions (i.e. target and severity) they categorized workplace deviance into four types; Property deviance, Production deviance, Political deviance and Personal aggression. Further, founded on the four categories of deviance, they also identified two primary types of workplace deviance that is interpersonal and organizational deviance. Where interpersonal deviance refers to deviant behavior toward individuals within an organization like co-workers, supervisors and subordinates, whereas, organizational deviance refers to deviant behavior towards the organization (details shown in figure 1). On basis of the critical review of the past studies (Robinson \& Bennett, 1995; Bennett \& Robinson, 2003; Kidder, 2005; Bordia et al., 2008; Ambrose \& Schminke, 2009; Omar et al., 2011; Fagbohungbe et al., 2012). The current study uses interpersonal and organizational deviance, as suggested by Robinson and Bennett (1995). For the reason as it covers not only the deviant behavior from the individual facet but also views deviant behavior from the organizational side. Secondly, it can improve the understanding as how Taqwa would impact at individual and organizational level, leading to valuable implications for managing the issue of workplace deviance. Moving further, it is essential to recognize as to why employees in an organization indulge themselves in deviant behavior.

\begin{tabular}{|c|c|c|}
\hline & Minor & Serious \\
\hline \multirow[t]{5}{*}{ Organizational } & Production deviance & Property deviance \\
\hline & - Leaving early from office & - Sabotaging office equipment \\
\hline & - Taking excessive breaks & - Accepting kickbacks \\
\hline & - Intentionally working slow & - Lying about working hours \\
\hline & - Wasting company resources & - Stealing from company \\
\hline \multirow[t]{5}{*}{ Interpersonal } & Political deviance & Personal aggression \\
\hline & - Showing favoritism & - Sexual harassment \\
\hline & - Gossiping about co-workers & - Verbal abuse \\
\hline & • Blaming co-workers & - Stealing from co-workers \\
\hline & - Competing non beneficially & • Endangering co-workers \\
\hline
\end{tabular}

Figure 1. Robinson and Bennett (1995) typology of deviant workplace behavior 


\subsection{Antecedents of Workplace Deviance}

Aquino et al. (1999); Colbert et al. (2004) affirm that antecedents of workplace deviance can be classified into two categories; 1) Individual antecedents, and 2) Situational antecedents. Considering individual difference, a range of personality traits have been acknowledged and recognized as related to workplace deviance and other forms of counterproductive behavior. Such as, anger (Douglas \& Martinko, 2001; Hershcovis et al., 2007), negative affectivity (Aquino et al., 1999), the Big Five personalities (Berry et al., 2007) and demographical characteristics (Feshbach, 1997; Feshbach, Feshbach, \& Jaffe, 1997; Hershcovis et al., 2007) are related to Individual antecedents. Whereas, with reference to Robinson and Bennett (1997), situational factors like inequity, injustice, unfair supervisor treatment, monetary pressures, social pressures, poor working conditions, organizational changes, and so forth are considered as antecedents of deviance. However, one of the most commonly studied situational antecedents is organizational justice (Barnett et al., 1994; McCardle, 2007; Hastings \& Finegan, 2011; Nurmaya, 2012).

\subsection{Organizational Justice}

Folger and Cropanzano (1998) affirm that organizational justice refers to the equality and fairness in decisions that organization makes, fairness in procedures that organization follows along with the interpersonal treatment employees receive. Thus, organizational justice exhibits the role of fairness and equality perceived and supposed by the workers in a workplace (Byrne \& Cropanzano, 2001; Greenberg \& Cropanzano, 2001; Hassan, 2002; Colquitt et al., 2005; Cropanzano et al., 2007; Colquitt \& Rodell, 2011). The organizational justice construct has developed and evolved over time, moreover, organizational justice has been classified into four dimensions that are distributive justice, procedural justice, interpersonal justice and informational justice (Colquitt, 2001; Colquitt \& Rodell, 2011).

Distributive justice considers perceptions of fairness of outcomes and takes into consideration issues such as equity, equality, and needs (Adams, 1965; Blau, 1968; Folger \& Konovsky, 1989; Greenberg, 1990b). Similarly, procedural justice refers to the perceived fairness of the procedures concerned with decision making and implementing decisions (Folger \& Greenberg, 1985; Lind \& Tyler, 1988) through which outcomes are allocated (Thibaut \& Walker, 1975; Leventhal, 1976; Kim \& Mauborgne, 1997). Further, Interactional justice is defined as a perception that an individual holds in regards to the treatment during the ratification of organizational decisions and procedures, including various "human-side" behaviors showcasing social sensitivity, for instance respect, honesty, dignity, and politeness, perform by the benefactor towards the beneficiary (Colquitt, 2001; Luo, 2007). And informational justice refers to the degree of justification and truthfulness offered to employees toward communicating information and knowledge about procedures and outcomes (Greenberg, 1993; Colquitt, 2001; Colquitt \& Rodell, 2011).

Theoretically as well as empirically, perceived organizational justice is related to workplace deviance (Barnett et al., 1994; Colquitt et al., 2001; Bennett \& Robinson, 2003; Vardi \& Weitz, 2004; Kidder, 2005; McCardle, 2007; Hastings \& Finegan, 2011; Nurmaya, 2012). Cohen-Charash and Spector (2001) affirmed that distributive justice is considerably linked with counterproductive behaviors, such as disagreement, conflict and negative emotion (Forret \& Love, 2008; Syaebani \& Sobri, 2011). Similarly, Ambrose, Seabright, and Schminke (2002) affirmed that when employees perceive procedural injustice, they tend to damage and sabotage their organization. Moreover, procedural injustice encourages employees to be aggressive with their supervisors (Greenberg \& Barling, 1999). Investigations show that supervisors more or less are believed to be the source of interactional injustice, as they can determine the quality of interpersonal treatment (Cropanzano, Prehar, \& Chen, 2002). Rude and insulting supervision often involves hostility, rudeness, public criticism, and bad temper. Such a supervisory conduct can trigger low levels of perceived organizational justice, leading to higher levels of psychological distress and turnover, and less positive attitude towards work and the organization (Barnett et al., 1994; Tepper, 2000; Davis \& Rothstein, 2006; Tepper et al., 2009). Researchers (Colquitt et al., 2001; Bobocel \& Zdaniuk, 2005; Davis \& Rothstein, 2006) also affirm that an explanation not clarifying the decision made by the management may trigger negative behavior among employees.

\subsection{Possible Solution to Overcome Workplace Deviance}

Notably, the discussion moves further in a direction to find a possible solution to overcome the issue of workplace deviance. The possible solution that may overcome deviant behavior and establish a just environment is by the promotion of workplace spirituality (Sulaiman et al., 2013b). Spirituality is expected to stimulate employee's honesty, creativity, commitment and personal fulfillment (Krishnakumar \& Neck, 2002). Research supports the belief that workplace spirituality programs in an organization do certainly result in encouraging positive outcomes like increased joy, serenity, job satisfaction and commitment (Krishnakumar \& Neck, 2002; 
Fry, 2003; Giacalone \& Jurkiewicz, 2003; Reave, 2005). Milliman, Czaplewski, and Ferguson (2003) in their investigation found a positive correlation between workplace spirituality and employee attitudes, for example; commitment to the organization, intrinsic work satisfaction, and job involvement. Neck and Milliman (1994) stated that spiritual values positively influence and affect an individual's well-being and job performance. Importantly, organizations that support and encourage spiritual and caring work environments not only benefit from employees who are less apprehensive and more principled but also see an increase in the commitment, productivity, adaptability and innovation in their employees (Eisler \& Montouori, 2003; Mat \& Naser, 2012).

This study aims at adding another dimension to the antecedents of workplace deviance in the form of socially responsible behavior of employees (social responsibility at individual level). The social responsibility concept has been mostly studied at the corporate level, wherein a corporation is treated as a social citizen (Appelbaum et al., 2007; Kolodinsky et al., 2010). An organization being a microcosm of a society, the socially responsible behavior of its members is expected to affect the overall behavior of the organization.

In Islam, spirituality and social responsibility both fall under the purview of Taqwa (Islamic Piety). Hence, the present study attempts to deepen and enrich the understanding of Taqwa and workplace deviance along with organizational justice in light of Islamic inheritance. For this reason, it is exceedingly significant to understand the fundamental concepts of Islamic Worldview, Akhlaq (morality and ethics in Islam) and Taqwa (Islamic Piety).

\subsection{The Islamic Worldview}

The magnificence of Islam is that it provides man with a complete and comprehensive worldview. Al-Attas (2001), in his renowned book titled "Prolegomena to the metaphysics of Islam", states that "Worldview', according to the perspective of Islam, is the vision of reality and truth that appears before our minds' eyes revealing what existence is all about; for it is the world of existence in totality that Islam is projecting" Al-Attas (2001, p. 2). The worldview of Islam covers not only the aspect al-dunya (worldly) but also al-akhirah (the hereafter), in which the aspect of dunya must be related in a profound as well as inseparable way to the aspect of akhirah and where the akhirah-aspect has the crucial and ultimate importance. Significantly the aspect of dunya is seen and deemed as a preparation for the akhirah-aspect (Kamil et al., 2011). Furthermore, in Islam Man is to follow the guidance and commands of Allah (SWT) in all walks of life. Man must live this life with the consciousness to please and gratify Allah (SWT) to emerge successful in the final test that is the hereafter. Hence, Islamic ontology presents a dual worldview that is; this world (universe) and the hereafter (Shahul, 2001).

The Islamic worldview includes the fundamental concept of God, core concept of man, nature/universe and the religion (Haneef, 1997; Kamil et al., 2011). Haneef (1997) asserts that an understanding of these essential concepts shape the ideologies and the vision with which an individual acts.

\subsubsection{Concept of God}

In Islamic worldview, the most essential and core concept which pervades all portions of life is the unity of God or Tawhid (Haneef, 1997; Saleem, 2009; Kamil et al., 2011). Tawhid literally means unification or asserting oneness (Bilal, 1994) that there is no god but God (Saleem, 2009). As quoted by Haneef (1997, p. 44), Allah (SWT) (God, Lord) in Quran says "To be a Muslim is to believe in the Oneness of God (Quran, 112:1- 4) and to have God always present in one's life. There is first and foremost ontological demarcation between God and everything else". This directs us to the basic understanding that "Muslims are inclined towards a self-check method in themselves owing to the consciousness and awareness of the constant existence of God (Allah) in them and everywhere" (Kamil et al., 2011, p. 17). Therefore, by submitting oneself to Allah (SWT), Muslims are in the state of absolute worship, as Allah (SWT) (God) is the ultimate cause and end of everything. This fundamental belief of Muslims together with the truth of submitting themselves to Allah (SWT) will have a high level of compassion to exhibit and show justice while working in any position or organization, resulting in overcoming the dilemma and problem of workplace deviance.

\subsubsection{The Concept of Man}

Haneef (1997) articulates that "man is at once a khalifah (vicegerent) on earth and abd (servant) of God (Quran 2:30). The role of khalifah implies that nature, universe, and the other creations are entrusted to man for his utilization. Whereas, the role of man as abd means that he/she does not have any independent authority or absolute rights other than those conferred on him/her by Allah" (Haneef, 1997, p. 45; Kamil et al., 2011, p. 17). Indeed, both these roles (i.e., Khalifah (vicegerent) and $a b d$ (servant) of God) have to be lived in chorus and any neglect or evasion of either one would not facilitate man to function as his true self (Haneef, 1997).

It is significant to understand that man being the Khalifah (vicegerent) needs to safeguard nature and all other 
creatures to which he/she is in contact with (Haneef, 1997; Kamil et al., 2011). Hence, Muslim Employees should protect and safeguard all those who are in contact with them, as this belief allows them to see the organization as a form of a gift and trust for which he/she is a caretaker and a custodian (Kamil et al., 2011).

\subsubsection{The Concept of Nature/ Universe}

Haneef (1997) affirms that in Islam, universe/nature constitutes of heavens and the earth and all in between, a phrase which reappears several times in the Quran. The nature/universe is principally one more sign and indication given to man to direct and devote him to worship Allah (SWT) (Haneef, 1997). Haneef (1997) further adds that besides the visible or the material world, there is also the world of the ghaib (invisible) which is equally real and existing to the Muslim.

The explanation provided by Kamil et al. (2011) clarifies and improves the understanding of the above concept presented by Haneef (1997). As Kamil et al. (2011) affirm "that when a non-Muslim looks at a beautiful and well-maintained garden, he/she may immediately end it by admiring and praising it as a beautiful garden with lovely and beautiful flowers. However, for a Muslim, he/she does not only see the beauty of the garden or flowers but also the creation, wisdom, vision and the existence of Allah (SWT) the Almighty. In other words, the Muslim deems that the garden exists to serve a particular purpose and the sole responsibility of the Muslim as a khalifah (custodian) is to take good care of the garden"(Kamil et al., 2011, p. 18). In simple words, a Muslim firmly believes that the garden exists to serve a specific purpose and man being Allah's (SWT) Khalifah must take good care of the garden (Kamil et al., 2011). This very concept may automatically lead a Muslim to display justice and abstain from workplace deviance in an organization, as he/she knows and understands that it is an act of worship.

\subsubsection{The Concept of Religion (Din)}

Islam is not only a religion but it is a complete way of life (Al-Habshi, 1987; Alam, 1998). The term "way of life" is extracted from the Arabic word "din". According to Murata and Chittick (1996), "din" literally means to obey, to conform, to be submissive and to serve. It is only this world that Man is being tested and solicited by Allah (SWT) to follow and practice the straight path or right path of the din (religion) to be successful and victorious in Hereafter (Haneef, 1997). Haneef (1997) posits that "according to God's will it is in this world that man is made khalifah and given the amanah (trust) to manage the world accordingly. It is in this world that man is given the liberty of preference concerning right and wrong, good and bad, and moreover to arrange his/her life in accordance to God's commandments, i.e., to be a servant of God or not. It is also to this world where God's message has been sent through Prophets for guiding man to follow the true and right path, establishing his/her place in the next enduring life. In this sense, the din of Islam, to wit, submission to God is meaningful and significant only in this world, as in the hereafter, man will no longer be having tests or "choices". Man's position in the next world will be the end result of the actions in this world" Haneef (1997, p. 47).

\subsection{Akhlaq (Ethics and Morality)}

In creating the need for organizational justice from Islamic perspective and overcoming the issue of workplace deviance, another important Islamic concept worth examining is Akhlaq (Islamic view of ethics and morality). The word "Akhlaq" is derived from the word "Kulq" which literally means nature, a natural and innate disposition or temper (Saleem, 2009). It ascribes to a person's moral character, his/her inner state, nature and peculiar qualities or attributes. It also means morality and ethics (Saleem, 2009). (Saleem, 2009, p. 3) states that, "Ethics is the study of human conduct, not as it is, but as it should be" and "Islam has commanded its followers to adhere to good moral and ethical values (Akhlaq)".

"The scope of Akhlaq in Islam is wider than that of ethics and morality, as Akhlaq covers not only the behavioral aspects but also an individual's relationship with Allah and purification of inner self (nafs)" (Saleem, 2009, p. 4). Allah (SWT) at various occasions in the Quran commands the establishment of justice and fair play amongst people. Similarly, Allah (SWT) also recommends kindness and forgiveness and refers to the need of guarding against moral corruption that is displaying the best of Akhlaq. In Quran Allah (SWT) says: "And verily, you (O Muhammad (PBUH)) are on an exalted (standard of) character" (Quran, 68:4). "Indeed in the Messenger of Allah (Muhammad (PBUH)) you have a good example to follow for him who hopes for (the Meeting with) Allah and the Last Day and remembers Allah much" (Quran, 33:21). Thus, Muslims are commanded by Allah to follow the Messenger of Allah (PBUH), in all factions of life if they want to attain the Mercy of Allah and His Forgiveness. As life of Muhammad (PBUH) the Messenger of Allah is a complete guide for us as Muslims to practice and show the best of Akhlaq. Abu Hurairah narrated that Prophet Muhammad has said: "Indeed I have been sent to complete the best of character (Akhlaq)" (Sahih Muslim, 6017). 
A Muslim is commanded to purify his/her soul through avoidance of sins. It is vital that a Muslim should not indulge in lying, backbiting, slandering or making false promises. Similarly should restrain and purify his/her soul from greed, jealously, excessive anger, miserliness (bukhul), ostentation (riya) and pride or arrogance (Saleem, 2009). In Quran Allah (SWT) states: "Do not shout. Speak politely keeping your voice low" (Quran, 31:19). "Always speak the truth. Shun words that are deceitful and ostentatious" (Quran, 22:30). Allah (SWT) also commands that: "Do not confound truth with falsehood" (Quran, 2:42) and "Say with your mouth what is in your heart" (Quran, 3:167). "Speak in a civilized manner in a language that is recognized by the society and is commonly used" (Quran, 4:5). "When you voice an opinion, be just, even if it is against a relative" (Quran, 6:152). "Do not be bragging boasters" (Quran, 31:18). "Do not talk, listen or do anything vain" (Quran, 23:3; 28:55). "Do not participate in any paltry. If you pass near a futile play, then pass by with dignity" (Quran, 25:72). Allah (SWT) also says that "Do not verge upon any immodesty or lewdness whether surreptitious or overt" (Quran, 6:151).Hence, a Muslim is commanded by Allah to be truthful in his dealings, fulfill promises, be honest, just and sincere in his/her actions and intensions, observe patience, gratitude and attain God- consciousness (Taqwa) (Saleem, 2009).

In business, trade and other economic matters an environment of justice and trust can only be shaped once people deal with each other honestly and fulfill their agreements and promises (Saleem, 2009). Lack of moral values could lead to greed, corruption, misuse of power and authority. Eventually putting together the element of dissatisfaction and increasing the feeling of being treated with prejudice. This directs us to the belief that fair and ethical behavior whether in private or in organization is deeply embedded in the Islamic belief system to which Muslims must observe at all times (Kamil et al., 2011). Therefore, a Muslim should always exhibit the best of his/her Akhlaq and restrain from deviant behavior.

\subsection{Taqwa (Islamic Piety)}

The spirit and meaning of life is found in Taqwa and living a life of Taqwa fundamentally means being a true friend to Allah (SWT) and possessing a heart that can understand and recognize the deepest depth of Devine blessings (Topbas, 2009). One of the most important and the frequent characteristic that Allah (SWT) directed and bounded its Messengers and all the believers to hold to is Taqwa, as declared in Quran. The word Taqwa is an important matter for our happiness not only in this life but the Hereafter. Allah (SWT) states 258 times in Quran providing various directions as how one can achieve Taqwa. It is highly evident from the Quran that Allah (SWT) wants us to have Taqwa at each and every stage of our lives that is in our worship, in our faith, actions in fact with every breath we take (Topbas, 2009).

\subsubsection{Definition of Taqwa}

The root of the word Taqwa is from wiqaya which is staying away from what has been forbidden (Ibn Kather, 2003). As Taqwa is to protect and reserve, Al-Sharawi (2004) affirms that Taqwa is to avoid Allah's (SWT) punishment by doing as what He commands and keeping away from what He forbids. Beekun and Badawi (1999) define Taqwa as all-encompassing, inner consciousness of one's duty towards Him and the awareness of one's accountability towards Him". In view of Ali (1997), Taqwa is the fear of running counter to the will of Allah (SWT); it is akin to the love of him; for we fear to offend those we love; it results in right conduct, and those who entertain it are those who would do right.

Taqwa is also conceptualized as a state of absolute maturity in which mind, heart and body are united and completely synchronized (Al-Atrash, 2002). Importantly whoever believes and observes the rule of Allah (SWT) in private and public is a person of Taqwa (Al-Atrash, 2002; Hawa, 2004). Similarly, Taqwa makes the heart in state of realization and consciousness of Allah's (SWT) existence and presence, hoping for His acceptance, fearing His punishment, and hesitating to commit any wrongdoing that might bring Allah's wrath (Qutob, 1986).

Taqwa is manifested in all facets of human behavior that includes his soul and body (Ibrahim, 1997). In Quran Allah (SWT) defines Taqwa by describing the characteristics of Motaqeen (people who possess Taqwa) as Allah (SWT) states: "This is the Book; in it is guidance sure, without doubt, to those who fear Allah. Who believe in the Unseen, are steadfast in prayer, and spend out of what We have provided for them. And who believe in the Revelation sent to thee, and sent before thy time, and (in their hearts) have the assurance of the Hereafter" (Quran, 2: 1-4). The present research thus, will visualize and envision Taqwa as such based on the above literature. However, to be able to understand Taqwa it is important to study the characteristics of Motaqeen, i.e. people who possess Taqwa in accordance with the Quran and Sunnah.

\subsubsection{Characteristics of Motaqeen}

As stated earlier Motaqeen are individuals who possess Taqwa. In various chapters and verses of Quran Allah 
(SWT) describes and mentions about the characteristics of those who hold Taqwa. Allah (SWT) states in Quran: "O you who believe! Stand out firmly for Allah as just witnesses and let not the enmity and hatred of others make you avoid justice. Be just: that is nearer to Taqwa, and fear Allah. Verily, Allah is Well-Acquainted with what you do. Allah has promised those who believe (in the Oneness of Allah - Islamic Monotheism) and do deeds of righteousness, that for them there is forgiveness and a great reward (i.e. Paradise)" (Quran, 5: 8-9). From the following Quranic verses it is evident that while doing justice one must always have fear of Allah (SWT). An individual does not need to be carried away by his/her extreme dislike for some people. Rather one needs to be just with everyone and everybody, whether a friend or an enemy. This is why Allah (SWT) has said "Be just: that is nearer to Taqwa". Also, Allah (SWT) promises forgiveness and great rewards to those who accept True Faith and follow Islamic Monotheism and do good deeds. Notably it is clear from the verses that being "just" is one of the basic characteristics and quality of a Motaqeen.

Mohsen (2007) affirms that Allah (SWT) describes Motaqeen as individuals who spend their riches and wealth while they are in need for it, as they are young during prosperity or difficulty for the needy. They also manage and control their anger and keep it with themselves and not at all act out of anger. Once anger is controlled and not acting on basis of anger, the Motaqeen forgives and holds no grudges in their hearts for the people who have caused pain or treated them in unjust manner. A Motaqeen always seeks for forgiveness on his/her wrong-doing and stops doing wrong deeds as well as in no way obstinate (Mohsen, 2007). Further, Allah (SWT) describes Motaqeen as individuals who believe in Allah (SWT), His Names, Sefat, the Day of Judgment, the Paradise, the Hell, the Angles, and the Books that Allah (SWT) revealed to all the Prophets (peace be upon all of them) and the Prophets (peace be upon all of them) themselves. Distinctiveness of a Motaqeen is that he/she should give charity to the needy especially one's relatives who are in need. Similarly performing regular prayers, paying zakat, honoring all commitments one makes and being patient during difficult times are the characteristics of a Motaqeen (Mohsen, 2007).

The key and essential characteristics of a Motaqeen that one can abstract from the Quran are; 1) Belief (Iman), 2) Abiding Prayers, 3) Seeking Allah (SWT) forgiveness, 4) Zakat (Charity), 5) Fasting, 6) Hajj, 7) Emotional control, 8) Forgivingness. 9) Restraining from wrong doings, 10) Patience, 11) Justice and 12) Truthfulness. Since, the present research aims to provide an appropriate solution to the issue of workplace deviance and maintaining a just environment. It is significant to understand and recognize that the qualities and characteristics of Motaqeen as stated by Allah (SWT) in Quran, once fully ingrained by business leaders can eventually create an environment that is equitable, fair and just for everyone.

\subsubsection{The Dimensions and Components of Taqwa}

The preceding section helps in understanding the qualities and characteristics of a Motaqeen. These characteristics of Motaqeen from the Quranic verses gave rise to two components of Taqwa which are Islamic Spirituality and Islamic Social Responsibility (Kamil et al., 2011b; Kamil et al., 2011; Mohsen, 2007; Ramli \& Osman-Gani, 2011).

It is evident from the Islamic literature that human beings consist of two parts; the physical part and the spirit part (Mohsen, 2007; Kamil et al., 2011; Kamil et al., 2011b; Ramli \& Osman-Gani, 2011; Sulaiman et al., 2013). In Quran Allah (SWT) states: "So, when I have fashioned him completely and breathed into him (Adam) the soul which I created for him, then fall (you) down prostrating yourselves unto him" (Quran, 15:29). The Arabic word for spirituality is "rawahaniyah". It is derived from the word "ruh" which means "spirit" (Mohsen, 2007). Nasr (1987) posits that spirituality is deep-rooted in "Iman" (faith) demonstrated by the Islamic rituals of prayers, fasting, pilgrimage (hajj) and zakat as these rituals are ways by which Muslims move close to Allah (SWT). Similarly, Al-Gazali (2004) also affirms that Ibadah (prayers) such as; salat, fasting, zakat and hajj ought to improve an individual's relationship with Allah (SWT) and people, if not they become empty ritual with no worth and value. Moreover, all the rituals that Allah (SWT) has instructed man to carry out are simply for their own benefit and gain so that one could reach to the highest state of spirituality and physical fitness (Ibrahim, 1997). Hawa (2004) supporting Ibrahim (1997) also indicated that through the performing of rituals (for instance prayers, hajj, zakat, reading Quran and fasting) one can achieve purification of the soul. Therefore, the theoretical definition of Islamic spirituality is the responsibility between one's self and Allah (SWT) (Mohsen, 2007; Kamil et al., 2011b; Sulaiman et al., 2013b). As the present research is the context of business, hence, Islamic spirituality refers to faith, actions and behaviors which are aligned with the Islamic principles and teachings that a Muslim must always place into practice in an organization for achieving the pleasure, help and forgiveness of Allah (SWT).

The study conducted by Mohsen (2007) revealed that Islamic Spirituality component comprises of three 
dimensions; Belief (Faith), Rituals and Repentance. However, Kamil et al. (2011a \& 2011b) moving one step forward affirmed that the Islamic Spirituality component comprises not three but four key dimensions that is; Belief (Faith), Rituals, Repentance/Forgiveness (Tawbah/Al-afw) and Remembrance of Allah (SWT) (Dhikrullah). Importantly, the compulsory requirements by all Muslims, such as prayer, zakat, hajj, fasting are grouped under Rituals (Ibadat).This is followed by the Islamic Spirituality dimensions of Repentance/Forgivingness (Tawbah/Al-afw) and Remembrance of Allah (SWT) (Dhikrullah) (Kamil et al., 2011b; Kamil et al., 2011). All other remaining characteristics fall under the Islamic Social Responsibility component (Kamil et al., 2011; Sulaiman et al., 2013).

According to Mohsen (2007) Islamic Responsibility is the responsibility to one's self and to other human beings and the nature at large. For this research, Islamic Social Responsibility is defined as actions and behaviors that Muslims execute and carry out in an organization that results in respect, harmony, justice, integrity and development of people and society with the realization of achieving forgiveness and pleasure of Allah (SWT). The components and dimensions as discussed based on the Study of Mohsen (2007) and Kamil et al. (2011) can be seen in Figure 2.

\begin{tabular}{|c|c|c|c|}
\hline & Belief (Iman) & & Belief (Iman) \\
\hline & $\begin{array}{l}\text { Prayers } \\
\text { Fasting } \\
\text { Hajj } \\
\text { Zakah } \\
\end{array}$ & Islamic Spirituality & Rituals (Ibadat) \\
\hline & $\begin{array}{l}\text { Asking for Allah's forgiveness } \\
\text { Never Obstinate in doing the wrong } \\
\text { Dhikrullah }\end{array}$ & & $\begin{array}{l}\text { Repentance /Asking Forgivingness } \\
\text { (Tawbah / Al-afw) } \\
\text { Dhikrullah }\end{array}$ \\
\hline Taqwa & $\begin{array}{l}\text { Patience } \\
\text { Emotional Control } \\
\text { Forgivingness } \\
\text { Sadaqah } \\
\text { Justice } \\
\text { Integrity } \\
\text { Fulfillment of Cov. } \\
\text { Guarding chastity } \\
\text { Truthfulness } \\
\text { Love of Family }\end{array}$ & 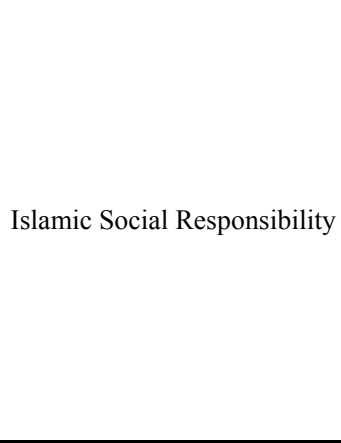 & $\begin{array}{l}\text { Patience } \\
\text { Emotional Control } \\
\text { Forgivingness } \\
\text { Sadaqah } \\
\text { Justice } \\
\text { Integrity } \\
\text { Fulfillment of Cov. } \\
\text { Guarding chastity } \\
\text { Truthfulness } \\
\text { Love of Family }\end{array}$ \\
\hline
\end{tabular}

Figure 2. The components and dimensions of Taqwa based on the characteristics of Motaqeen

Note. *The components and dimensions of Taqwa based on the characteristics of Motaqeen as shown in the figure is a modified version presented by Kamil et al. (2011);(2011b); Kamil (2012).

Source: Mohsen (2007) and Kamil et al. (2011a; 2011b).

\subsection{Proposed Conceptual Framework}

Taqwa as discussed earlier comprises of two dimensions that are Islamic spirituality and Islamic social responsibility. An individual, manager, director or leader with high level of spirituality and strong sense of responsibility towards his/her dealings, job and actions is well committed and motivated and holds a high level of team spirit and cooperation (Mohsen, 2007; Sulaiman et al., 2013b). Researchers (Krishnakumar \& Neck, 2002; Fry, 2003; Eisler \& Montouori, 2003; Giacalone \& Jurkiewicz, 2003; Reave, 2005; Mat \& Naser, 2012) also argue that spirituality is expected to stimulate an employee's honesty, creativity, commitment, personal fulfillment, increased joy, serenity, job satisfaction, commitment, productivity and adaptability. Hence, based on the literature review it is suggested that there is a relationship between Taqwa (comprising of the two dimensions that are Islamic spirituality and Islamic social responsibility) and workplace deviance.

It is further proposed on basis of the literature review to take into account perceived organizational justice as a moderator to further analyze the relationship between Taqwa and workplace deviance. As the social exchange theory (Thibuat \& Kelley, 1959; Blau, 1964) with the norm of reciprocity (Gouldner, 1960) deems that employees respond to the treatment they receive from there seniors, bosses or coworkers. Likewise, social 
learning theory (Bandura, 1977) avows that people display or portray their behavior based on the behaviors they observe from the environment. What's more, a number of scholars (Greenberg, 1990a; Skarlicki \& Folger, 1997; Bies, 2001; Ambrose et al., 2002; Spector \& Fox, 2005; Colquitt et al., 2006) have argued that if organizational decisions and actions are deemed unfair, employees experience feelings of outrage, resentment, retaliation, revenge, counterproductive workplace behaviors and workplace sabotage. Importantly, employees with strong interpersonal justice values, or justice orientations, are unlikely to engage in workplace deviance, regardless of their interpersonal justice perceptions (Holtz \& Harold, 2009). Hence, the hypothesized relationship between Taqwa and workplace deviance may vary depending on perceived organizational justice as a moderator.

Figure 3 illustrates the proposed model and the key relationships that are to be tested in this present study. The model suggests that Islamic spirituality and Islamic social responsibility influences workplace deviance. Moreover, the relationship between Taqwa and workplace deviance will be moderated by organizational justice.

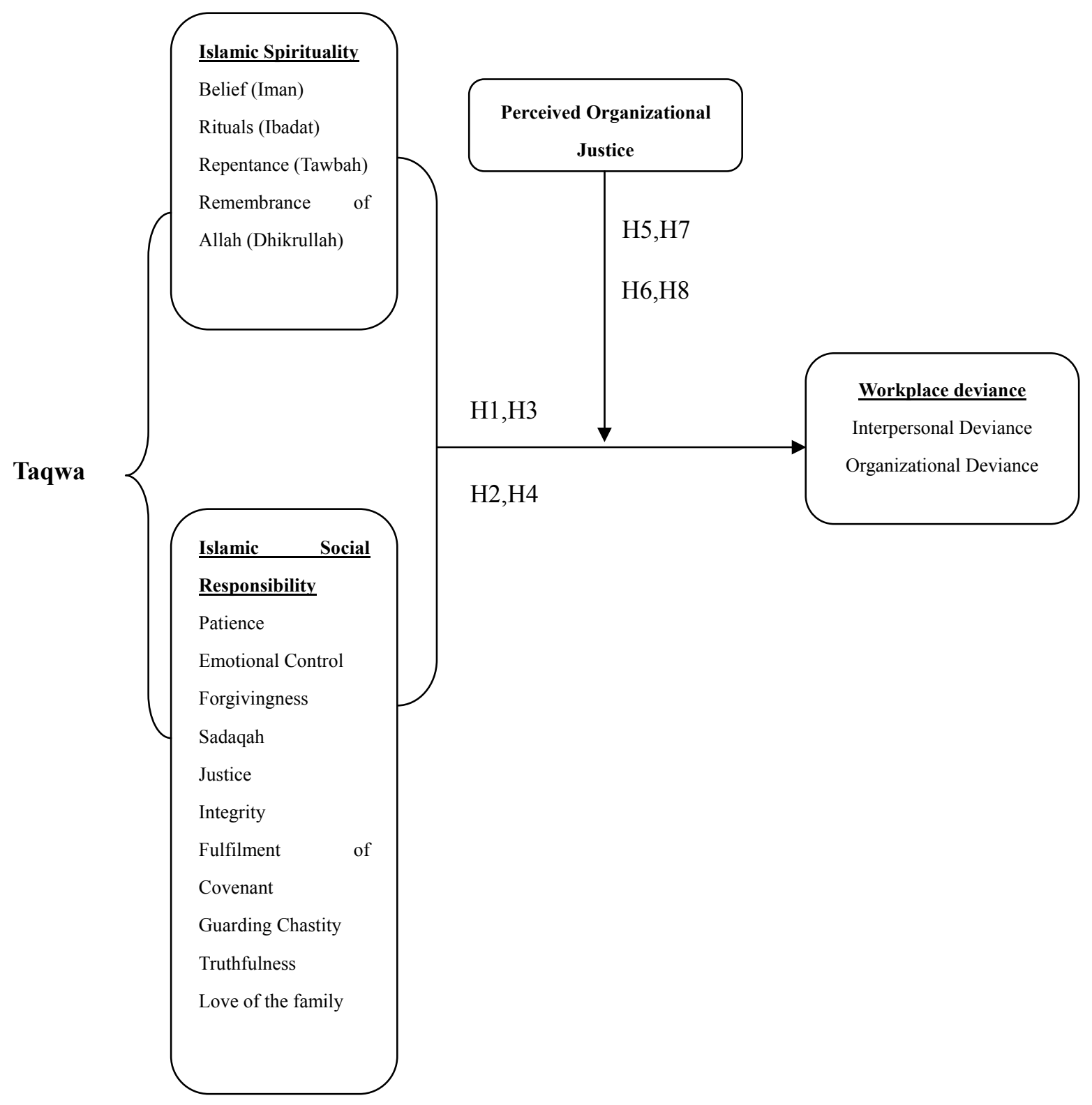

Figure 3. Proposed research framework

\section{Hypotheses}

Based on the above discussion, the following main and sub-hypothesis are presented:

H1: There is a negative relationship between Islamic spirituality and Interpersonal deviance. 
H1.1: There is a negative relationship between Belief and Interpersonal deviance.

H1.2: There is a negative relationship between Rituals and Interpersonal deviance.

H1.3: There is a negative relationship between Repentance and Interpersonal deviance.

H1.4: There is a negative relationship between Remembrance of Allah and Interpersonal deviance.

$\mathrm{H} 2$ : There is a negative relationship between Islamic social responsibility and Interpersonal deviance.

H2.1: There is a negative relationship between Patience and Interpersonal deviance.

H2.2: There is a negative relationship between Emotional control and Interpersonal deviance.

$\mathrm{H} 2.3$ : There is a negative relationship between Forgiveness and Interpersonal deviance.

$\mathrm{H} 2$.4: There is a negative relationship between Sadaqah and Interpersonal deviance.

$\mathrm{H} 2.5$ : There is a negative relationship between Justice and Interpersonal deviance.

H2.6: There is a negative relationship between Integrity and Interpersonal deviance.

H2.7: There is a negative relationship between Fulfillment of Covenant and Interpersonal deviance.

H2.8: There is a negative relationship between Guarding Chastity and Interpersonal deviance.

H2.9: There is a negative relationship between Truthfulness and Interpersonal deviance.

H3: There is a negative relationship between Islamic spirituality and Organizational deviance.

H3.1: There is a negative relationship between Belief and Organizational deviance.

H3.2: There is a negative relationship between Rituals and Organizational deviance.

H3.3: There is a negative relationship between Repentance and Organizational deviance.

H3.4: There is a negative relationship between Remembrance of Allah and Organizational deviance.

H4: There is a negative relationship between Islamic social responsibility and Organizational deviance.

H4.1: There is a negative relationship between Patience and Organizational deviance.

H4.2: There is a negative relationship between Emotional control and Organizational deviance.

H4.3: There is a negative relationship between Forgiveness and Organizational deviance.

H4.4: There is a negative relationship between Sadaqah and Organizational deviance.

H4.5: There is a negative relationship between Justice and Organizational deviance.

H4.6: There is a negative relationship between Integrity and Organizational deviance.

H4.7: There is a negative relationship between Fulfillment of Covenant and Organizational deviance.

H4.8: There is a negative relationship between Guarding Chastity and Organizational deviance.

H4.9: There is a negative relationship between Truthfulness and Organizational deviance.

H5: Perceived organizational justice moderates the relationship between Islamic Spirituality and Interpersonal deviance.

H5.1: Perceived organizational justice moderates the relationship between Belief and Interpersonal deviance.

H5.2: Perceived organizational justice moderates the relationship between Rituals and Interpersonal deviance.

H5.3: Perceived organizational justice moderates the relationship between Repentance and Interpersonal deviance.

H5.4: Perceived organizational justice moderates the relationship between Remembrance of Allah and Interpersonal deviance.

H6: Perceived organizational justice moderates the relationship between Islamic social responsibility and Interpersonal deviance.

H6.1: Perceived organizational justice moderates the relationship between Patience and Interpersonal deviance.

H6.2: Perceived organizational justice moderates the relationship between Emotional control and Interpersonal deviance.

H6.3: Perceived organizational justice moderates the relationship between Forgiveness and Interpersonal deviance. 
H6.4: Perceived organizational justice moderates the relationship between Sadaqah and Interpersonal deviance.

H6.5: Perceived organizational justice moderates the relationship between Justice and Interpersonal deviance.

H6.6: Perceived organizational justice moderates the relationship between Integrity and Interpersonal deviance.

H6.7: Perceived organizational justice moderates the relationship between Fulfillment of Covenant and Interpersonal deviance.

H6.8: Perceived organizational justice moderates the relationship between Guarding Chastity and Interpersonal deviance.

H6.9: Perceived organizational justice moderates the relationship between Truthfulness and Interpersonal deviance.

H7: Perceived organizational justice moderates the relationship between Islamic Spirituality and Organizational deviance.

H7.1: Perceived organizational justice moderates the relationship between Belief and Organizational deviance.

H7.2: Perceived organizational justice moderates the relationship between Rituals and Organizational deviance.

H7.3: Perceived organizational justice moderates the relationship between Repentance and Organizational deviance.

H7.4: Perceived organizational justice moderates the relationship between Remembrance of Allah and Organizational deviance.

H8: Perceived organizational justice moderates the relationship between Islamic social responsibility and Organizational deviance.

H8.1: Perceived organizational justice moderates the relationship between Patience and Organizational deviance.

H8.2: Perceived organizational justice moderates the relationship between Emotional control and Organizational deviance.

H8.3: Perceived organizational justice moderates the relationship between Forgiveness and Organizational deviance.

H8.4: Perceived organizational justice moderates the relationship between Sadaqah and Organizational deviance.

H8.5: Perceived organizational justice moderates the relationship between Justice and Organizational deviance.

H8.6: Perceived organizational justice moderates the relationship between Integrity and Organizational deviance.

H8.7: Perceived organizational justice moderates the relationship between Fulfillment of Covenant and Organizational deviance.

H8.8: Perceived organizational justice moderates the relationship between Guarding Chastity and Organizational deviance.

H8.9: Perceived organizational justice moderates the relationship between Truthfulness and Organizational deviance.

\section{Conclusion}

This study attempted to explain the phenomena of workplace deviance by proposing a new theoretical framework and empirical relationship, yielding a new model of workplace deviance from Islamic perspective. In particular, the study will investigate the direct relationship between Taqwa and workplace deviance, as well as, the moderating effect of perceived organizational justice on the hypothesized relationship of Taqwa and Workplace deviance.

This study attempts to fill the literature gap on workplace deviance, perceived organizational justice and Taqwa (Islamic piety). In addition, CEO's, General Managers and managers by applying this workplace deviance model may manage and reduce the incidence of workplace deviance. And can assist them to understand the impact of perceived injustice on employee's attitude and behavior. Further, the findings of this study may provide non-Muslim professionals and employees with better understanding of the belief and values of their Muslim employees or Muslim colleagues.

\section{References}

Adams, J. S. (1965). Inequity in social exchange. Advances in experimental social psychology. New York: Academic Press. 
Alam, K. (1998). Islam, ethics and accounting practices. Accounting, Commerce and Finance: The Islamic Perspective Journal, 2(2), 67-85.

Al-Atrash. (2002). Hakekat AlTaqwa. Alexandria: Dar- Aliman.

Al-Attas, S. M. (2001). Prolegomena: To the metaphysics of Islam. An exposition of the fundamental elements of the worldview of Islam. Kuala Lumpur: International Institute of Islamic Thought and Civilization.

Al-Gazali, M. (2004). Khuluk Almuslim (Muslim's Behavior). Damascus: Dar Alkalam.

Al-Habshi, S. O. (1987). The role of ethics in economics and business. Journal of Islamic Economics, 1(1), 1-15.

Ali, A. Y. (1997). The meaning of the Quran. Maryland: Amana publications.

Al-Sharawi, M. (2004). Mafatih al-rizk wa abwab al-faraj (The keys to wealthy lives and the doors to success). Cairo: Al Tawfikia Publications.

Altaf, M., Afzal, H., Hamid, K., \& Jamil, M. (2011). Empirical analysis of organizational justice towards employee's customer oriented behavior: A case study of Medical Institutions in Pakistan. African Journal of Business Management, 5(4), 1286-1292.

Ambrose, M. L., \& Schminke, M. (2009). The role of overall justice judgments in organizational justice research: A test of mediation. Journal of Applied Psychology, 94(2), 491-500.

Ambrose, M. L., Seabright, M. A., \& Schminke, M. (2002). Sabotage in the workplace: The role of organizational injustice. Organizational Behavior and Human Decision Processes, 89(1), 947-965.

Anderson, L. M., \& Pearson, C. M. (1999). Tit for tat? The spiraling effect of incivility in the workplace. Academy of Management Review, 452-471.

Appelbaum, S. H., Iaconi, G. D., \& Matousek, A. (2007). Positive and negative deviant workplace behaviors: causes, impacts, and solutions. Corporate Governance, 7(5), 586-598.

Aquino, K., Galperin, B. L., \& Bennett, R. J. (2004). Social status and aggressiveness as moderators of the relationship between interactional justice and workplace deviance. Journal of Applied Social Psychology, 34, 1001-1029. http://dx.doi.org/10.1111/j.1559-1816.2004.tb02581.x

Aquino, K., Lewis, M. U., \& Bradfield, M. (1999). Justice constructs, negative affectivity, and employee deviance: A proposed model and empirical test. Journal of Organizational Behavior, 20(7), 1073-1091. http://dx.doi.org/10.1002/(SICI)1099-1379(199912)20:7<1073::AID-JOB943>3.0.CO;2-7

Aryee, S., Budhwar, P. S., \& Chen, Z. X. (2002). Trust as a mediator of the relationship between organizational justice and work outcomes: Test of a social exchange model. Journal of Organizational Behavior, 23(3), 267-285. http://dx.doi.org/10.1002/job.138

Bandura, A. (1977). Social learning theory. Englewood Cliffs, NJ: Prentice-Hall.

Barnett, T., Bass, K., \& Brown, G. (1994). Ethical Ideology and Ethical Judgment Regarding Ethical Issues in Business. Journal of Business Ethics, 13(6), 469-480.

Beekun, R. I., \& Badawi, J. (1999). Leadership: An Islamic Perspective. Kuala Lumpur: Amana Publications.

Bennett, R. J., \& Robinson, S. L. (2003). The past, present, and future of workplace deviance research (2nd ed.). Mahwah, NJ: Lawrence Erlbaum Associates.

Berry, C. M., Ones, D. S., \& Sackett, P. R. (2007). Interpersonal deviance, organizational deviance, and their common correlates: A review and meta-analysis. Journal of Applied Psychology, 92(2), 410-424. http://dx.doi.org/10.1037/0021-9010.92.2.410

Bies, R. J., \& Tripp, T. M. (1996). Beyond distrust: "Getting even" and the need for revenge. Newbury Park, CA: Sage.

Bilal, P. A. A. (1994). The fundamentals of tawheed (Islamic monotheism). Riyadh: Islamic Publishing House.

Blau, P. M. (1964). Exchange and power in social life. New York: Wiley.

Blau, P. M. (1968). Social exchange. International Encyclopedia of the Social Sciences. New York: MacMillan.

Bobocel, D. R., \& Zdaniuk, A. (2005). How can explanations be used to foster organizational justice? New York: Lawrence Erlbaum.

Bordia, P., Restubog, S. L. D., \& Tang, R. L. (2008). When employees strike back: Investigating mediating mechanisms between psychological contract breach and workplace deviance. Journal of Applied 
Psychology, 93(5), 1104. http://dx.doi.org/10.1037/0021-9010.93.5.1104

Brown, M. E., \& Trevino, L. K. (2006). Socialized charismatic leadership, values congruence, and deviance in work groups. Journal of Applied Psychology, 91(4), 954. http://dx.doi.org/10.1037/0021-9010.91.4.954

Byrne, Z. S., \& Cropanzano, R. (2001). The history of organizational justice: The founders speak. Justice in the Workplace: From Theory to Practice, 2, 3-26.

Case, J. (2000). Employee Theft: The Profit Killer. Del Mar, CA: John Case \& Associates.

Chirasha, V., \& Mahapa, M. (2012). An Analysis of the Causes and Impact of Deviant Behavior in the Workplace. The Case of Secretaries in State Universities. Emerging Trends in Economics and Management Sciences (JETEMS), 3(5), 415-421.

Cohen-Charash, Y., \& Spector, P. E. (2001). The role of justice in organizations: A meta-analysis. Organizational Behavior and Human Decision Processes, 86(2), 278-321.

Colbert, A. E., Mount, M. K., Harter, J. K., Witt, L., \& Barrick, M. R. (2004). Interactive effects of personality and perceptions of the work situation on workplace deviance. Journal of Applied Psychology, 89(4), 599. http://dx.doi.org/10.1037/0021-9010.89.4.599

Colquitt, J. A. (2001). On the dimensionality of organizational justice: A construct validation of a measure. Journal of Applied Psychology, 86(3), 386-400. http://dx.doi.org/10.1037/0021-9010.86.3.386

Colquitt, J. A., \& Rodell, J. B. (2011). Justice, trust, and trustworthiness: A longitudinal analysis integrating three theoretical perspectives. Academy of Management Journal, 54(6), 1183-1206.

Colquitt, J. A., \& Shaw, J. C. (2005). How should organizational justice be measured? Mahwah, NJ: Lawrence Erlbaum.

Colquitt, J. A., Conlon, D. E., Wesson, M. J., Porter, C. O. L. H., \& Ng, K. Y. (2001). Justice at the millennium: a meta-analytic review of 25 years of organizational justice research. Journal of Applied Psychology, 86(3), 425-445.

Cropanzano, R., Bowen, D. E., \& Gilliland, S. W. (2007). The Management of Organizational Justice. Academy of Management Perspectives, 21(4), 34-48.

Cropanzano, R., Prehar, C. A., \& Chen, P. Y. (2002). Using social exchange theory to distinguish procedural from interactional justice. Group \& Organization Management, 27(3), 324-351.

Davis, A. L., \& Rothstein, H. R. (2006). The effects of the perceived behavioral integrity of managers on employee attitudes: A meta-analysis. Journal of Business Ethics, 67(4), 407-419.

Diefendorff, J. M., \& Mehta, K. (2007). The relations of motivational traits with workplace deviance. Journal of Applied Psychology, 92(4), 967.

Douglas, S. C., \& Martinko, M. J. (2001). Exploring the role of individual differences in the prediction of $\begin{array}{lllll}\text { workplace aggression. Journal of Applied Psychology, } & 86(4), & 547 .\end{array}$ http://dx.doi.org/10.1037/0021-9010.86.4.547

Eisler, R., \& Montouori, A. (2003). The human side of spirituality. New York: M. E. Sharp, Inc.

Fagbohungbe, B. O., Akinbode, G. A., \& Ayodeji, F. (2012). Organizational Determinants of Workplace Deviant Behaviours: An Empirical Analysis in Nigeria. International Journal of Business and Management, 7(5), 207-221. http://dx.doi.org/10.5539/ijbm.v7n5p207

Feshbach, S. (1997). The psychology of aggression: Insights and issues. Aggression: Biological, developmental, and social perspectives. New York: Plenum.

Feshbach, S., Feshbach, N., \& Jaffe, Y. (1997). A longitudinal study of the relationship between aggressive and depressive tendencies in elementary school age boys and girls. Aggression: Biological, developmental, and social perspectives. New York: Plenum.

Folger, R., \& Cropanzano, R. (1998). Organizational justice and human resource management. Thousand Oaks, CA: Sage.

Folger, R., \& Greenberg, J. (1985). Procedural justice: An interpretive analysis of personnel systems. Research in Personnel and Human Resources Management, 3, 141-183.

Folger, R., \& Konovsky, M. A. (1989). Effects of procedural and distributive justice on reactions to pay raise decisions. Academy of Management Journal, 32(1), 115-130. 
Forret, M., \& Love, M. S. (2008). Employee justice perceptions and coworker relationships. Leadership \& Organization Development Journal, 29(3), 248-260. http://dx.doi.org/10.1108/01437730810861308

Fry, L. W. (2003). Toward a theory of spiritual leadership. The Leadership Quarterly, 14(6), 693-727. http://dx.doi.org/10.1016/j.leaqua.2003.09.001

Giacalone, R. A., \& Greenberg, J. (1997). Antisocial behavior in organizations. Sage Publications, Incorporated.

Giacalone, R. A., \& Jurkiewicz, C. L. (2003). Right from wrong: The influence of spirituality on perceptions of unethical business activities. Journal of Business Ethics, 46(1), 85-97. http://dx.doi.org/10.1023/A:1024767511458

Gouldner, A. W. (1960). The norm of reciprocity: A preliminary statement. American Sociological Review, 161-178.

Greenberg, J. (1990a). Employee theft as a reaction to underpayment inequity: The hidden cost of pay cuts. Journal of Applied Psychology; Journal of Applied Psychology, 75(5), 561-568. http://dx.doi.org/10.1037/0021-9010.75.5.561

Greenberg, J. (1990b). Organizational justice: Yesterday, today, and tomorrow. Journal of Management, 16(2), 399-432.

Greenberg, J. (1993). The social side of fairness: Interpersonal and informational classes of organizational justice. Englewood Cliffs, NJ: Erlbaum.

Greenberg, J., \& Cropanzano, R. (2001). Advance in organizational justice. Stanford, CA: Stanford University Press.

Greenberg, L., \& Barling, J. (1999). Predicting employee aggression against coworkers, subordinates and supervisors: The roles of person behaviors and perceived workplace factors. Journal of Organizational Behavior, 20(6), 897-913.

Griffin, R. W., \& Lopez, Y. P. (2005). "Bad Behavior" in Organizations: A Review and Typology for Future Research. Journal of Management, 31(6), 988-1005. http://dx.doi.org/10.1177/0149206305279942

Gross-Schaefer, Trigilio, J., Negus, J., \& Ro, C. S. (2000). Ethics Education in the Workplace: An Effective Tool to Combat Employee Theft. Journal of Business Ethics, 26, 89-100.

Hamid, A. H. (1999). Islam the natural way. Kuala Lumpur. A. S. Noordeen: A. S. Noordeen.

Haneef, M. A. M. (1997). Islam, the Islamic worldview and Islamic economics. IIUM Journal of Economics and Management, 5(1), 39-66.

Harper, D. (1990). Spotlight abuse-Save profits. Industrial Distribution, 7, 47-51.

Hashim, J. (2011). Human Resources Management Practices in Islam and Organizational Outcomes. In Osman-Gani \& Sarif (Eds.), Spirituality in Management from Islamic perspective. International Islamic University Malaysia: IIUM press.

Hassan, A. (2002). Organizational justice as a determinant of organizational commitment and intention to leave. Asian Academy of Management Journal, 7(2), 55-66.

Hastings, S. E., \& Finegan, J. E. (2011). The Role of Ethical Ideology in Reactions to Injustice. Journal of Business Ethics, 100, 689-703.

Hawa, S. (2004). Tarbeitena Alruhia. Cairo: Dar-Alsalam.

Hershcovis, M. S., Turner, N., Barling, J., Arnold, K. A., Dupré, K. E., Inness, M., \& Sivanathan, N. (2007). Predicting workplace aggression: A meta-analysis. Journal of Applied Psychology, 92(1), 228.

Hollinger, R., \& Clark, J. (1982). Employee Deviance A Response to the Perceived Quality of the Work Experience. Work and Occupations, 9(1), 97-114. http://dx.doi.org/10.1177/0730888482009001006

Huda, A. (2009). Statistics about Muslim population of the world.

Ibn Kather Al-Qurashi Al-damashqi, A. I. (2003). Tafsir Al-Quran Al-kareem. Madina: Darul Taibati Printing Press.

Ibrahim, M. (1997). Alkeiadah Altarbawih Fi Alislam. Amman: Jordan: Dar- Magdlawi.

Iqbal, Z. M., Arif, I. M., Badar, S., \& (2012). A Comparative Study of Deviant Workplace Behavior of Teaching Staff of Public and Private Universities of Punjab-Pakistan. International Journal of Asian Social Science, 
2(12), 2128-2137.

Kamil, N. M. (2012). Organizational citizenship behavior from Islamic perspective and the role of Taqwa: Emprical analysis of business organizations in Malaysia. International Islamic University Malaysia.

Kamil, N. M., Al-Kahtani, A. H., \& Sulaiman, M. (2011b). The components of spirituality in the business organizational context: The case of Malaysia. Asian Journal of Business and Management Sciences, 1(2), 166-180.

Kamil, N. M., Sulaiman, M., Osman-Gani, M. A., \& Ahmad, K. (2011). Implications of Taqwa on Organizational Citizenship Behavior. In Osman-Gani \& Sarif (Eds.), Spirituality in Management from Islamic perspective. International Islamic University Malaysia: IIUM press.

Kaplan, H. B. (1975). Self-attitudes and deviant behavior. Pacific Palisades, CA: Goodyear.

Kidder, D. L. (2005). Is it 'who I am', 'what I can get away with', or 'what you've done to me'? A Multi-theory Examination of Employee Misconduct. Journal of Business Ethics, 57, 389-398.

Kidwell, R. E., \& Martin, C. L. (2004). Managing organizational deviance. Sage Publications, Incorporated.

Kim, W., \& Mauborgne, R. (1997). Fair Process: Managing in the Knowledge Economy. Harvard Business Review.

Kolodinsky, R. W., Madden, T. M., Zisk, D. S., \& Henkel, E. T. (2010). Attitudes about corporate social responsibility: Business student predictors. Journal of Business Ethics, 91(2), 167-181.

Krishnakumar, S., \& Neck, C. P. (2002). The "what", "why" and "how" of spirituality in the workplace. Journal of Managerial Psychology, 17(3), 153-164. http://dx.doi.org/10.1108/02683940210423060

Lawrence, B. T., \& Robinson, L. S. (2007). Ain't Misbehavin: Workplace Deviance as Organizational Resistance. Journal of Management, 33(3), 378-394.

Leventhal, G. S. (1976). The distribution of rewards and resources in groups and organizations. Advances in Experimental Social Psychology, 9, 91-131.

Lind, E. A., \& Tyler, T. R. (1988). The social psychology of procedural justice. New York: Plenum.

Luo, Y. (2007). The independent and interactive roles of procedural, distributive, and interactional justice in strategic alliances. Academy of Management Journal, 50(3), 644-664.

Mangione, T. W., \& Quinn, R. P. (1974). Job satisfaction, counterproductive behavior, and drug use at work. Journal of Applied Psychology, 60(1), 114. http://dx.doi.org/10.1037/h0076355

Mat, N., \& Naser, N. M. (2012). Workplace Spatiality and Counterproductive Work Behavior (CWB): A Malaysian Perspective. Paper presented at the 3rd International Conference on Business and Economic Research Proceeding, Bandung, Indonesia.

McCardle, J. G. (2007). Organizational justice and workplace deviance: The role of organizational structure, powerlessness, and information salience. $\mathrm{PhD}$ Thesis, University of Central Florida Orlando, Florida.

Milliman, J., Czaplewski, A. J., \& Ferguson, J. (2003). Workplace spirituality and employee work attitudes: An exploratory empirical assessment. Journal of Organizational Change Management, 16(4), 426-447.

Mitchell, M. S., \& Ambrose, M. L. (2007). Abusive supervision and workplace deviance and the moderating effects of negative reciprocity beliefs. Journal of Applied Psychology, 92(4), 1159. http://dx.doi.org/10.1037/0021-9010.92.4.1159

Mohsen, N. R. M. (2007). Leadership from the Quran, operationalization of concepts and empirical analysis: Relationship between Taqwa, trust and business leadership effectiveness. PhD Thesis, Universiti Sains Malaysia, Kuala Lumpur, Malaysia.

Murata, S., \& Chittick, W. C. (1996). The vision of Islam. London: I.B. Tauris.

Nasir, M., \& Bashir, A. (2012). Examining workplace deviance in public sector organizations of Pakistan. International Journal of Social Economics, 39(4), 240-253.

Nasr, S. H. (1987). Islamic spirituality. London: Routledge \& Kegan Paul.

Neck, C., \& Milliman, J. (1994). Thought self-leadership: Finding spiritual fulfillment in organizational life. Journal of Managerial Psychology, 9(6), 9-16.

Nurmaya, E. (2012). Perceived Organizational Justice and Workplace Deviance: The Mediating Role of 
Psychological Contract Breach and Psychological Contract Violation. Doctor of Business Administration UKM, Malaysia.

Omar, F., Halim, F., Zainah, A., \& Farhadi, H. (2011). Stress and Job Satisfaction as Antecedents of Workplace Deviant Behavior. Deviant Behavior, 16, 17.

Pulich, M., \& Tourigny, L. (2004). Workplace deviance: strategies for modifying employee behavior. The Health Care Manager, 23(4), 290-301.

Qutob, S. (1986). Tafsir Fi Zilal Al- Quran. Kaherah, Mesir: Dar Syuruk.

Ramli, E. L., \& Osman-Gani, A. M. (2011). Spirituality in leadership from Islamic Perspective. In Osman- Gani \& Sarif (eds) Spirituality in Management from Islamic perspective. International Islamic University Malaysia: IIUM press.

Reave, L. (2005). Spiritual values and practices related to leadership effectiveness. The Leadership Quarterly, 16(5), 655-687. http://dx.doi.org/10.1016/j.leaqua.2005.07.003

Robinson, S. L., \& Bennett, R. J. (1995). A typology of deviant workplace behaviors: A multidimensional scaling study. Academy of Management Journal, 38(2), 555-572. http://dx.doi.org/10.2307/256693

Robinson, S. L., \& Bennett, R. J. (1997). Workplace deviance: its definition, its nature, and its causes. Research on Negotiation in Organizations, 6, 3-28.

Sackett, P. R., \& DeVore, C. J. (2001). Counterproductive behaviors at work. Handbook of Industrial, Work, and Organizational Psychology. http://dx.doi.org/10.4135/9781848608320.n9

Saleem, M. Y. (2009). An introduction to the theoretical foundations of Islamic transactions. Ilmiah Publishers.

Shahul, H. M. I. (2001). Islamic accounting-Accounting for the new millennium? Paper presented at the Asia Pacific Conference 1, Kota Bharu, Malaysia.

Shahzad, A., \& Mahmood, Z. (2012). The Mediating-Moderating Model of Organizational Cynicism and Workplace Deviant Behavior. (Evidence from Banking Sector in Pakistan). Middle-East Journal of Scientific Research, 12(5), 580-588.

Spector, P. E., \& Fox, S. (2005). The Stressor-Emotion Model of Counterproductive Work Behavior. Washington, DC: American Psychological Association.

Sulaiman, M., \& Bhatti, O. K. (2013). Workplace Deviance and spirituality in Muslim Organizations. Asian Social Science, 9(10), 237-246. http://dx.doi.org/10.5539/ass.v9n10p237

Sulaiman, M., Mohsen, M. R. N., \& Kamil, N. M. (2013). The Role of Spirituality and responsibility on Business Leadership Effectiveness: An Empirical Analysis in the Republic of Yemen. Paper presented at the 3rd Int. Management Conference, Bandung, Indonesia.

Syaebani, I. M., \& Sobri, R. (2011). Relationship between Organizational Justice Perception and Engagement in Deviant Workplace Behavior. The South East Asian Journal of Management, 5(1), 37-49.

Tepper, B. J. (2000). Consequences of abusive supervision. Academy of Management Journal, 43(2), 178-190. http://dx.doi.org/10.2307/1556375

Tepper, B. J., Carr, J. C., Breaux, D. M., Geider, S., Hu, C., \& Hua, W. (2009). Abusive supervision, intentions to quit, and employees' workplace deviance: A power/dependence analysis. Organizational Behavior and Human Decision Processes, 109(2), 156-167. http://dx.doi.org/10.1016/j.obhdp.2009.03.004

Thibaut, J., \& Walker, L. (1975). Procedural Justice. Hillsdale: NJ Erlbaum

Thibuat, J., \& Kelley, H. (1959). The social psychology of groups. New York: Wiley.

Topbas, N. O. (2009). Ikhlas and Taqwa Sincerity and Piety. Istanbul-Turkey: Erkam Print House.

Vardi, Y. (2001). The Effects of Organizational and Ethical Climates on Misconduct at Work. Journal of Business Ethics, 29, 25-337. http://dx.doi.org/10.1023/A:1010710022834

Vardi, Y., \& Weitz, E. (2004). Misbehavior in organizations: Theory, research, and management. Hillsdale: Erlbaum.

Warren, D. E. (2003). Constructive and destructive deviance in organizations. Academy of Management Review, 28(4), 622-632. http://dx.doi.org/10.1037/a0012695 


\section{Copyrights}

Copyright for this article is retained by the author(s), with first publication rights granted to the journal.

This is an open-access article distributed under the terms and conditions of the Creative Commons Attribution license (http://creativecommons.org/licenses/by/3.0/). 